\title{
IMPLEMENTASI ASAS DROIT DE PREFERENCE TERHADAP JAMINAN HAK TANGGUNGAN OLEH PIHAK PERBANKAN DALAM PERJANJIAN KREDIT
}

\author{
Lila Kurniawati Khisni", Lathifah Hanim **
}

\begin{tabular}{l} 
* Mahasiswa Program Magister (S2) Kenotariatan Fakultas Hukum UNISSULA, Semarang, e-mail: \\
lilakurniawati83@gmail.com \\
** Dosen Fakultas Hukum UNISSULA, Semarang email: lathifah@unissula.ac.id \\
\hline
\end{tabular}

\section{ABSTRACT}

This study entitled Implementation of the principle of droit de preference to the guarantee of mortgage rights by the banks in the credit agreement. This study discusses the implementation of the principle of droit de preference on the guarantee of mortgage rights by the banks in credit agreements, the constraints found in the implementation of the principle of droit de preference on the guarantee of mortgage rights by the banks in credit agreements and how to overcome these obstacles.

Implementation of the principle of droit de preference on the guarantee of mortgage by PT Bank Tabungan Pensiunan Nasional, Tbk in credit agreement Number 122 Credit Agreement in which to guarantee payment of all amount owed and obliged to be paid by debtor to bank either arising based on credit agreement and or Any change / renewal / renewal thereof then the debtor hereby deposits to the bank the guarantees which the transfer of ownership rights is evidenced by documents and agreements made in the form, amount and content satisfying the bank in the form of four plots of land. Constraints in the implementation of the principle of droit de preference on the guarantee of mortgage rights by the banks in the credit agreement include the difficulty of banks to conduct surveys on collateral pledged by debtors, difficulties in assessing the price of land and buildings by the bank other than that the debtor's academic ability in Understand all the contents of the agreement so that only give confidence to the bank to complete all the documentation related to the credit agreement process. The solution to overcome these obstacles is that the Bank checks to the Land Affairs Office because that is where the completeness of land documents, and the bank conducts field surveys after the credit agreement is implemented and by looking at the Land and Building Tax Payment Letters as the Value of Tax Objects and provide detailed explanation and Detailed on each article of the credit agreement so that the debtor will understand and understand each article of the credit agreement to be signed.

Keywords: Droit de Preference Principle, Guarantee of Deposit Rights

\section{PENDAHULUAN}

\section{Latar Belakang}

Lembaga perbankan merupakan inti dari sistem keuangan dari setiap negara. Bank adalah lembaga keuangan yang menjadi tempat bagi orang perseorangan, badan-badan usaha swasta, badanbadan usaha milik negara bahkan lembaga-lembaga pemerintahan menyimpan dana yang dimilikinya. Melalui kegiatan perkreditan dan berbagai jasa yang diberikan, bank melayani kebutuhan pembiayaan serta mekanisme sistem pembayaran bagi semua sektor perekonomian. ${ }^{1}$

Pada hakekatnya lembaga keuangan adalah semua badan yang melalui kegiatan-kegiatannya di bidang keuangan menarik uang dari dan menyalurkannya ke dalam masyarakat. Sebagai lembaga keuangan, bank mempunyai usaha pokok berupa menghimpun dana dari masyarakat untuk kemudian menyalurkannya kembali kepada masyarakat yang membutuhkan dana dalam bentuk kredit atau pembiayaan. Fungsi untuk mencari dan menghimpun dana dari masyarakat dalam bentuk simpanan

1 Hermansyah, 2014, Perbankan Nasional Indonesia, Cetakan ke-8,Kencana Prenada Media, Jakarta, hal. 7 
memegang peranan penting terhadap pertumbuhan suatu bank, sebab volume dana yang berhasil dihimpun atau disimpan tentunya akan menentukan pula volume dana yang dapat dikembangkan oleh bank tersebut dalam bentuk penanaman dana yang menghasilkan misalnya dalam bentuk pemberian kredit. $^{2}$

Operasi bank di bidang pemberian fasilitas kredit adalah fungsi utama dari bisnis perbankan, yakni fungsi menyalurkan dana kepada mereka yang memerlukannya setelah menerima pengumpulan dana dari para deposan penyimpan dana. ${ }^{3}$

Dalam Penjelasan Pasal 8 Undang-undang Nomor 10 Tahun 1998 tentang Perubahan atas Undang-undang Nomor 7 Tahun 1992 tentang Perbankan, ditentukan bahwa kredit yang diberikan oleh bank mengandung risiko dan untuk mengurangi risiko tersebut bank harus mempunyai keyakinan atas kemampuan dan kesanggupan dari debitor untuk melunasi utangnya Untuk memperoleh keyakinan tersebut, sebelum memberikan kredit, bank melakukan penilaian yang seksama terhadap Watak, Kemampuan, Modal, Agunan/jaminan dan Prospek usaha

Bentuk lembaga jaminan sebagian besar mempunyai ciri-ciri internasional yang dikenal hampir di semua negara dan perundang-undangan modern yaitu bersifat menunjang perkembangan ekonomi dan perkreditan serta memenuhi kebutuhan masyarakat akan fasilitas modal ${ }^{4}$.

Oleh karena itu, dalam pengajuan kredit calon debitur diwajibkan untuk menjaminkan harta kekayaannya sebagai agunan seperti benda bergerak atau benda tidak bergerak. Salah satunya adalah hak milik atas tanah di mana di dalam proses kreditnya kemudian hak milik atas tanah tersebut akan dilakukan pembebanan hak tanggungan selama kredit belum selesai.

Istilah hak tanggungan dicantumkan dalam Pasal 51 Undang-undang Nomor 5 Tahun 1960 tentang Pokok-pokok Agraria bahwa hak tanggungan yang dapat dibebankan kepada hak milik, hak guna usaha, hak guna bangunan dalam Pasal 25, 33 dan

\footnotetext{
${ }^{2}$ Ibid., hal. 43

3 Gunarto Suhardi, 2003, Usaha Perbankan dalam Perspektif Hukum, Kanisius, Yogyakarta, hal. 75

4 Mariam Darus Badrulzaman,1983, Mencari Sistem Hukum Benda Nasional. Alumni, Bandung, hal. 37.
}

309 diatur dengan Undang-undang. Namun dengan telah berlakunya Undang-undang Nomor 4 Tahun 1996 tentang Hak Tanggungan Atas Tanah beserta Benda-benda yang berkaitan dengan Tanah maka diketahui bahwa tanah, bangunan dan tanaman yang ada merupakan suatu jaminan dalam peminjaman kredit karena sifatnya dapat dipindahtangankan dan dimungkinkan adanya suatu jaminan (security) bagi pihak yang meminjamkan uang maka istilah jaminan tanah sebagai agunan adalah Hak Tanggungan ${ }^{5}$

Pasal 8 Undang-undang Nomor 10 Tahun 1998 tentang Perubahan atas Undang-undang Nomor 7 Tahun 1992 tentang Perbankan, menyatakan "Kredit yang diberikan oleh bank mengandung risiko dan untuk mengurangi risiko tersebut bank harus mempunyai keyakinan atas kemampuan dan kesanggupan dari debitor untuk melunasi utangnya"

Untuk memperoleh keyakinan tersebut, sebelum memberikan kredit, bank melakukan penilaian yang seksama terhadap Watak, Kemampuan, Modal, Agunan/ jaminan dan Prospek usaha

Setelah lahirnya Undang-undang Nomor 4 Tahun 1996 tentang Hak Tanggungan Atas Tanah beserta Benda-benda Lain yang berkaitan dengan Tanah (UUHT) maka dualisme dalam penggunaan hak tanggungan seperti yang diuraikan di atas tidak akan ada lagi, namun untuk hypotheek dan ketentuan-ketentuannya masih ada sebagai lembaga hak jaminan bagi kapal-kapal tertentu menurut ketentuan Kitab Undang-undang Hukum Dagang Indonesia.

Sehubungan dengan itu maka selanjutnya hak tanggungan merupakan satu-satunya hak jaminan atas tanah dan dengan demikian tentulah unifikasi Hukum Tanah Nasional yang merupakan salah satu tujuan utama UUPA. Pemberian hak tanggungan harus dituangkan dalam Notaris/Akta Pejabat Pembuat Akta Tanah yang diatur dalam Pasal 10 ayat (2) Undang-undang Nomor 4 Tahun 1996 tentang Hak Tanggungan Atas Tanah beserta Bendabenda Lain yang berkaitan dengan Tanah (UUHT). Hak tanggungan sendiri memiliki ciri-ciri antara lain memberikan kedudukan yang diutamakan atau mendahulukan pemegangnya atau yang dikenal

5 Rudi Indrajaya dan Ika Ikmasari, 2016, Kedudukan Akta Izin Roya Hak Tanggungan sebagai Pengganti Sertifikat Hak Tanggungan Yang Hilang, Visimedia Pustaka, Jakarta, hal. 29 
dengan asas droit de preference

Arti droit de preference sendiri dalam praktik perbankan adalah bahwa pada penguasaan hak atas tanah merupakan wewenang untuk menguasai hak atas tanah di mana penguasaan hak atas tanah oleh kreditur bukan untuk menguasai secara fisik, namun untuk diutamakan kepada kreditor menjualnya jika debitor cidera janji. Perbankan sebagai kreditor yang menguasai asas droit de deference ini diberikan keutamaan untuk menjual tanah jaminan hak tanggungan milik debitur apabila debitur wanprestasi atau mengalami kredit macet.

Permasalahan dalam penulisan ini yaitu bagaimanakah implementasi asas droit de preference terhadap jaminan hak tanggungan oleh pihak perbankan dalam perjanjian kredit, apakah hambatanhambatan yang ditemukan dalam implementasi asas droit de preference terhadap jaminan hak tanggungan oleh pihak perbankan dalam perjanjian kredit dan bagaimana cara mengatasinya.

\section{PEMBAHASAN}

Jaminan umum yang di berikan Kitab UndangUndang Hukum Perdata tidak memuaskan bagi kreditur karena kurang menimbulkan rasa aman dan terjamin bagi kredit yang diberikan dengan tidak adanya kepastian akan pelunasan semua piutangnya akibat adanya kreditur lain, untuk itu kreditur memerlukan benda-benda tertentu milik debitur atau penjaminan dari orang lain atas hutang debitur yang ditunjuk secara khusus sebagai jaminan pelunasan hutangnya, dan ini hanya berlaku bagi si kreditur tersebut. Pengikatan benda tertentu milik debitur atau penjaminan seseorang atas hutang si debitur atas permintaan kreditur sebagai tambahan penjaminan untuk pelunasan hutang debitur dinamakan jaminan khusus.

Jaminan khusus memberikan kepada kreditur kedudukan yang lebih baik dalam hal penagihan, lebih baik daripada kreditur konkuren yang tidak memegang hak jaminan khusus atau dengan kata lain ia relative lebih terjamin dalam pemenuhan tagihannya, kedudukan yang lebih baik diantara para kreditur yang mempunyai hak jaminan khusus tidak sama, bergantung dari macam hak jaminan yang dipunyainya.

Kedudukan kreditur yang lebih baik dari kreditur lainnya disebut juga kreditur preference.
Droit de preference dimiliki oleh para kreditur yang memiliki hak kebendaan, yang diperoleh dengan mengikat perjanjian jaminan kebendaan terhadap benda tertentu milik debitur, cara pengikatan mana bersifat mutlak atas benda tertentu yang diikat, sehingga apabila debitur melakukan wanprestasi atau cidera janji, maka kreditur mempunyai hak terhadap benda yang diikat tersebut untuk mendapat pelunasan terlebih dahulu daripada kreditur lainnya.

Dalam praktek perbankan, adanya jaminan yang dikhususkan itu disyaratkan oleh suatu prinsip sebagaimana tercantum dalam Pasal 24 UndangUndang Pokok Perbankan Nomor 14 tahun 1967 yang melarang adanya pemberian kredit tanpa jaminan. Pasal 1 angka 23 Undang-Undang Nomor 10 Tahun 1998 Tentang perbankan yaitu agunan adalah jaminan tambahan yang diserahkan nasabah kepada bank dalam rangka pemberian fasilitas kredit

Bentuk lembaga jaminan kebendaan yang dikenal dalam Undang-Undang, baik itu hak tanggungan untuk hak atas tanah dan gadai untuk benda bergerak, mensyaratkan penyerahan jaminan ke dalam kekuasaan kreditur,sementara itu disisi lain banyak masyarakat yang membutuhkan kredit, khususnya untuk benda bergerak berharap masih bisa menggunakan benda jaminan tersebut untuk keperluan usahanya.

Jaminan kredit yang demikian tidak dapat ditampung dalam lembaga jaminan gadai, karena peraturan tentang gadai tidak memungkinkan benda jaminan tetap berada pada pihak yg menggadaikan, hal ini bertentangan dengan syarat inbezitstelling seperti yang tercantum dalam Pasal 1152 ayat 2 KUHPerdata yaitu adanya kewajiban melepaskan secara fisik benda-benda dari kekuasaan si pemberi gadai kepada pemegang gadai,yang disyaratkan dalam lembaga gadai.

Karena kebutuhan tersebut timbullah dalam praktek apa yang disebut jual beli dengan hak membeli kembali yang digunakan untuk menutupi suatu perjanjian pinjam meminjam uang dengan suatu jaminan pelunasan hutang. Pihak penjual/ debitur menjual barang-barangnya kepada pembeli/ kreditur dengan ketentuan bahwa barang tersebut tetap dikuasai debitur namun hanya sebagai peminjam pakai dan bila saatnya tiba, jangka waktu perjanjian berakhir, debitur akan membeli kembali barang yang sudah menjadi milik kreditur tersebut, 
tetapi barang masih tetap dalam penguasaan debitur, yang dinamakan fidusia.

Perjanjian jaminan merupakan perjanjian accessoir dari perjanjian kredit . Perjanjian jaminan hanya akan ada setelah adanya suatu perjanjian utang piutang atau perjanjian kredit. Perjanjian jaminan menimbulkan suatu hak bagi kreditor, dalam perjanjian jaminan kebendaan hak yang timbul adalah suatu hak kebendaan baru yang memberikan jaminan terhadap kreditor.

Pada prinsipnya tidak semua benda dapat dijaminkan pada lembaga perbankan atau lembaga keuangan non bank, namun benda yang dapat dijaminkan adalah benda-benda yang memenuhi syarat - syarat tertentu. Syarat- syarat benda

Jaminan yang baik adalah dapat secara mudah membantu perolehan kredit itu oleh pihak yang memerlukannya, tidak melemahkan potensi (kekuatan) si pencari kredit untuk melakukan atau meneruskan usahanya, memberikan kepastian kepada kreditor dalam arti bahwa benda jaminan setiap waktu tersedia untuk dieksekusi, bila perlu mudah diuangkan untuk melunasi hutangnya penerima (pengambil kredit ). Kitab Undang-Undang Hukum Perdata telah memberikan sarana perlindungan bagi kreditur sebagaimana tercantum dalam pasal 1131 KUHPerdata dan pasal 1132 KUHPerdata :

Pasal 1131 KUHPerdata : "Segala kebendaan si berutang, baik yang bergerak maupun yang tidak bergerak, baik yang sudah ada maupun yang baru aka nada di kemudian hari, menjadi tanggungan untuk segala perikatan perorangan". Pasal $1132 \mathrm{KUH}$ Perdata : "Kebendaan tersebut menjadi jaminan bersama-sama bagi semua orang yang mengutangkan kepadanya, pendapatan penjualan benda-benda itu dibagi menurut keseimbangan yaitu menurut besar kecil piutang masing- masing kecuali apabila diantara para berpiutang itu ada alasan yang sah untuk didahulukan."

Ketentuan Pasal 1131 KUH Perdata ini merupakan jaminan secara umum atau jaminan yang timbul dari Undang-Undang. Menurut pasal tersebut Undang-Undang memberikan perlindungan bagi semua kreditur dalam kedudukan yang sama, dimana berlaku asas paritas creditorium yaitu kedudukan para kreditur adalah sama. Dengan demikian para kreditur hanya berkedudukan sebagai kreditur konkuren, kecuali bila ada alasan yang mem- berikan kedudukan yang lebih utama di bandingkan dengan kreditur lain (droit de preference).

Droit de preference dimiliki oleh para kreditur yang memiliki hak kebendaan, yang diperoleh dengan mengikat perjanjian jaminan kebendaan terhadap benda tertentu milik debitur, cara pengikatan mana bersifat hak mutlak atas benda tertentu yang diikat, sehingga apabila debitur melakukan wanprestasi, maka kreditur mempunyai hak terhadap benda yang diikat tersebut untuk mendapat pelunasan terlebih dahulu daripada kreditur lainnya.

Jaminan kebendaan termasuk dalam hukum kebendaan, sehingga ciri-ciri hak kebendaan berlaku pula pada jaminan kebendaan yaitu Merupakan hak mutlak atas suatu benda, Kreditur mempunyai hubungan langsung dengan benda-benda tertentu milik debitur, Dapat dipertahankan terhadap tuntutan oleh siapapun, Selalu mengikuti bendanya ditangan siapapun benda itu berada (asas droit de suite), Mengandung asas prioritas yaitu hak kebendaan yang lebih dulu terjadi akan lebih diutamakan daripada yang terjadi kemudian (droit de preference), Dapat diperalihkan, Bersifat perjanjian tambahan ( accessoir).

Perjanjian jaminan kebendaan ditandai dengan suatu pemisahan bagian dari kekayaan seseorang yang dipergunakan untuk menjamin dan menyediakannya bagi pemenuhan kewajiban seorang debitur kepada kreditur atas hutangnya. Hak jaminan kebendaan memberikan hak-hak kepada kreditur untuk didahulukan dalam pengambilan pelunasan dibandingkan kreditur-kreditur lain yang tidak memiliki hak jaminan kebendaan.

Implementasi asas droit de preference terhadap jaminan hak tanggungan oleh pihak PT Bank Tabungan Pensiunan Nasional, Tbk dalam perjanjian kredit Perjanjian kredit di mana guna menjamin pembayaran semua jumlah uang yang terhutang dan wajib dibayar oleh debitur kepada bank baik yang timbul berdasarkan perjanjian kredit dan atau setiap perubahan/ perpanjangan/ pembaharuannya kemudian maka debitur dengan ini menyerahkan kepada bank jaminan-jaminan yang pengalihan hak kepemilikannya dibuktikan dengan dokumen dan perjanjian-perjanjian yang dibuat dalam bentuk, jumlah dan isi yang memuaskan bank yaitu berupa empat bidang tanah. Berdasarkan hal tersebut maka 
implementasi asas droit de preference terhadap jaminan hak tanggungan oleh pihak PT. Bank Tabungan Pensiunan Nasional, Tbk dalam Perjanjian Kredit.

Guna menjamin pembayaran semua jumlah uang yang terhutang dan wajib dibayar oleh debitur kepada bank baik yang timbul berdasarkan perjanjian kredit dan atau setiap perubahan /perpanjangan/ pembaharuannya kemudian maka debitur dengan ini menyerahkan kepada bank jaminan-jaminan yang pengalihan hak kepemilikannya dibuktikan dengan dokumen dan perjanjian-perjanjian yang dibuat dalam bentuk, jumlah dan isi yang memuaskan bank yaitu berupa tanah.

Hambatan di dalam implementasi asas droit de preference terhadap jaminan hak tanggungan oleh pihak PT. Bank Tabungan Pensiunan Nasional, Tbk dalam Perjanjian Kredit terdiri dari hambatan dari pihak perbankan atau kreditur dan hambatan dari pihak nasabah atau debitur.

Hambatan dari pihak perbankan antara lain kesulitan bank untuk melakukan survey atas jaminan yang diagunkan debitur karena jaminan yang diajukan debitur berupa tanah dan bangunan kadang berjumlah lebih dari satu bidang dan lokasinya terpisah-pisah, sedangkan pihak PT. Bank Tabungan Pensiunan Nasional, Tbk harus mengecek sendiri ke lapangan kebenaran lokasi tanah tersebut. Hal ini diatasi dengan pihak bank melakukan pengecekan ke Kantor Pertanahan di Tegal karena di sanalah terdapat kelengkapan dokumen pertanahan

Hambatan selanjutnya adalah kesulitan di dalam menaksir harga tanah dan bangunan oleh bank melihat perbandingan plafond pinjaman yang diajukan debitur sedangkan bidang tanah yang diajukan debitur belum tentu memiliki nilai nominal sebesar itu. Hal ini diatasi dengan Melakukan survey lapangan setelah perjanjian kredit dilaksanakan dan dengan melihat Surat Tanda Pembayaran Pajak Bumi dan Bangunan sebagai Nilai Jual Obyek Pajak

Sedangkan hambatan dari pihak debitur di dalam implementasi asas droit de preference terhadap jaminan hak tanggungan oleh pihak PT. Bank Tabungan Pensiunan Nasional, Tbk dalam Perjanjian Kredit adalah debitur tidak mengetahui harga sebenarnya dari jaminan yakni bidang tanah dibandingkan dengan plafond kredit yang diajukan. Apalagi jika plafond kredit yang diajukan jumlahnya sangat besar hingga ratusan juta bahkan milyaran rupuah. Hal ini diatasi dengan Pihak bank melakukan penafsiran harga tanah, selanjutnya memberitahukan kepada debitur mengenai hasil taksiran tersebut apakah memenuhi nilai plafond kredit yang diajukan atau tidak.

Debitur juga memiliki hambatan di dalam melakukan perjanjian kredit pada PT. Bank Tabungan Pensiunan Nasional, Tbk karena kemampuan akademis debitur di dalam memahami semua isi perjanjian sehingga hanya memberikan kepercayaan kepada pihak bank untuk melengkapi segala dokumentasi yang berkaitan dengan proses perjanjian kredit. Hal ini diatasi dengan pihak bank memberikan penjelasan dengan secara detail dan rinci mengenai setiap pasal dari perjanjian kredit sehingga pihak debitur akan memahami dan mengerti akan setiap pasal dari perjanjian kredit yang akan ditandatanganinya.

\section{PENUTUP}

Implementasi asas droit de preference terhadap jaminan hak tanggungan oleh pihak PT. Bank Tabungan Pensiunan Nasional, Tbk dalam Perjanjian Kredit di mana guna menjamin pembayaran semua jumlah uang yang terhutang dan wajib dibayar oleh debitur kepada bank baik yang timbul berdasarkan perjanjian kredit dan atau setiap perubahan /perpanjangan/pembaharuannya kemudian maka debitur dengan ini menyerahkan kepada bank jaminanjaminan yang pengalihan hak kepemilikannya dibuktikan dengan dokumen dan perjanjian-perjanjian yang dibuat dalam bentuk, jumlah dan isi yang memuaskan bank yaitu berupa tiga bidang tanah.

Hambatan-hambatan di dalam implementasi asas droit de preference terhadap jaminan hak tanggungan oleh pihak perbankan dalam perjanjian kredit adalah ambatan dari pihak perbankan antara lain kesulitan bank untuk melakukan survey atas jaminan yang diagunkan debitur, Hambatan selanjutnya adalah kesulitan di dalam menaksir harga tanah dan bangunan oleh bank melihat perbandingan plafond pinjaman yang diajukan debitur sedangkan bidang tanah yang diajukan debitur belum tentu memiliki nilai nominal sebesar jumlah kredit yang diajukan.

Solusi untuk mengatasi hambatan implementasi asas droit de preference terhadap jaminan hak 
tanggungan oleh pihak perbankan dalam perjanjian kredit tersebut adalah bahwa PT Bank Tabungan Pensiunan Nasional, Tbk harus mengecek sendiri ke lapangan kebenaran lokasi tanah tersebut dapat diatasi dengan pihak bank melakukan pengecekan ke Kantor Badan Pertanahan di Kabupaten Tegal karena di sanalah terdapat kelengkapan dokumen pertanahan, kemudian bank dapat mengatasinya dengan melakukan survey lapangan setelah perjanjian kredit dilaksanakan dan dengan melihat Surat Tanda Pembayaran Pajak Bumi dan Bangunan sebagai Nilai Jual Obyek Pajak. Hambatan selanjutnya dapat diatasi dengan pihak bank memberikan penjelasan dengan secara detail dan rinci mengenai setiap pasal dari perjanjian kredit sehingga pihak debitur akan memahami dan mengerti akan setiap pasal dari perjanjian kredit yang akan ditandatanganinya dan debitur di dalam memahami semua isi perjanjian sehingga hanya memberikan kepercayaan kepada pihak bank untuk melengkapi segala dokumentasi yang berkaitan dengan proses perjanjian kredit

\section{DAFTAR PUSTAKA}

Bayu Seto, Lex Mercataroia Baru dan Arah Pengembangan Hukum Kontrak Indonesia dalam Era Perdagangan Bebas, Tinjauan Singkat tentang Kedudukan Hukum Perjanjian Nasional dan Prospek Pengembangannya dalam Konteks Harmoniasai Hukum Kontrak di Kawasan ASEAN, makalah dalam rangka Dies Natalis Fakultas Hukum Universitas Parahyangan Bandung, 15 September 2003

Gunarto Suhardi, 2003, Usaha Perbankan dalam Perspektif Hukum, Kanisius, Yogyakarta

Hermansyah, 2014, Perbankan Nasional Indonesia, Cetakan ke-8,Kencana Prenada Media, Jakarta

Ignatius Ridwan Widyadarma, 1996, Undang-undang Hak Tanggungan atas Tanah beserta Bendabenda yang Berkaitan dengan Tanah,. Badan
Penerbitan Universitas Diponegoro, Semarang

Kitab Undang-undang Hukum Perdata

Lexi Moleong, 1990, Metodologi Penelitian Kualitatif, RemajaRosdakarya, Bandung

Mariam Darus Badrulzaman,1983, Mencari Sistem Hukum Benda Nasional. Alumni, Bandung

Ronny Hanintijo Soemitro, 1991, Metode Penelitian Hukum, Ghalia Indonesia, Jakarta

Rudi Indrajaya dan Ika Ikmasari, 2016, Kedudukan Akta Izin Roya Hak Tanggungan sebagai Pengganti Sertifikat Hak Tanggungan Yang Hilang, Visimedia Pustaka, Jakarta

Sahnan, 2016, Hukum Agraria Indonesia, Setara Press, Malang

Sanapsiah Faisal, 1980, Penelitian Kualitatif, Dasardasar Aplikasi, YA3, Malang

Singarimbun, 1989, Metode Penelitian Survey, LP3ES, Jakarta

Soerjono Soekanto, 1979, Pengantar Penelitian Hukum, Rajawali, Jakarta,

Undang-undang Nomor 1 Tahun 1960 tentang Pokok-Pokok Agraria

Undang-undang Nomor 10 Tahun 1998 tentang Perbankan

Undang-undang Nomor 4 Tahun 1996 tentang Hak Tanggungan Atas Tanah Beserta Benda-benda Yang Berkaitan Dengan Tanah

Witanto, 2015, Hukum Jaminan Fidusia dalam Perjanjian Pembiayaan Konsumen, Bandung: Mandar Maju

Zainuddin, 2014, Metode Penelitian Hukum, Jakarta: Sinar Grafika 